University of Nebraska - Lincoln

DigitalCommons@University of Nebraska - Lincoln

U.S. Environmental Protection Agency Papers

U.S. Environmental Protection Agency

2008

\title{
Human health risk assessment database, "the NHSRC toxicity value database": Supporting the risk assessment process at US EPA's National Homeland Security Research Center
}

\author{
Chandrika J. Moudgal \\ U.S. EPA, moudgal.chandrika@epa.gov \\ Kevin Garrahan \\ U.S. EPA \\ Eletha Brady-Roberts \\ U.S. EPA \\ Naida Gavrelis \\ Eastern Research Group, Inc. \\ Michelle Arbogast \\ Eastern Research Group, Inc. \\ See next page for additional authors
}

Follow this and additional works at: https://digitalcommons.unl.edu/usepapapers

Moudgal, Chandrika J.; Garrahan, Kevin; Brady-Roberts, Eletha; Gavrelis, Naida; Arbogast, Michelle; and Dun, Sarah, "Human health risk assessment database, "the NHSRC toxicity value database": Supporting the risk assessment process at US EPA's National Homeland Security Research Center" (2008). U.S. Environmental Protection Agency Papers. 172.

https://digitalcommons.unl.edu/usepapapers/172

This Article is brought to you for free and open access by the U.S. Environmental Protection Agency at DigitalCommons@University of Nebraska - Lincoln. It has been accepted for inclusion in U.S. Environmental Protection Agency Papers by an authorized administrator of DigitalCommons@University of Nebraska - Lincoln. 


\section{Authors}

Chandrika J. Moudgal, Kevin Garrahan, Eletha Brady-Roberts, Naida Gavrelis, Michelle Arbogast, and Sarah Dun 


\title{
Human health risk assessment database, "the NHSRC toxicity value database": Supporting the risk assessment process at US EPA's National Homeland Security Research Center ${ }^{\text {th }}$
}

\author{
Chandrika J. Moudgal a,*, Kevin Garrahan ${ }^{\text {a }}$, Eletha Brady-Roberts ${ }^{\text {a }}$, Naida Gavrelis ${ }^{\text {b }}$, \\ Michelle Arbogast ${ }^{\mathrm{b}}$, Sarah Dun ${ }^{\mathrm{b}}$ \\ a U.S. EPA/Office of Research and Development (ORD), National Homeland Security Research Center (NHSRC), USA \\ ${ }^{\mathrm{b}}$ Eastern Research Group, Inc. (ERG), USA
}

\section{A R T I C L E I N F O}

Article history:

Available online 15 July 2008

\section{Keywords:}

Toxicity

Risk assessment

TVD

Reference values

\begin{abstract}
A B S T R A C T
The toxicity value database of the United States Environmental Protection Agency's (EPA) National Homeland Security Research Center has been in development since 2004. The toxicity value database includes a compilation of agent property, toxicity, dose-response, and health effects data for 96 agents: 84 chemical and radiological agents and 12 biotoxins. The database is populated with multiple toxicity benchmark values and agent property information from secondary sources, with web links to the secondary sources, where available. A selected set of primary literature citations and associated dose-response data are also included. The toxicity value database offers a powerful means to quickly and efficiently gather pertinent toxicity and dose-response data for a number of agents that are of concern to the nation's security. This database, in conjunction with other tools, will play an important role in understanding human health risks, and will provide a means for risk assessors and managers to make quick and informed decisions on the potential health risks and determine appropriate responses (e.g., cleanup) to agent release. A final, stand alone MS ACESSS working version of the toxicity value database was completed in November, 2007.
\end{abstract}

Published by Elsevier Inc.

\section{Introduction}

The U.S. Environmental Protection Agency (EPA) needs tools and methods that will permit rapid response and inform risk-management decisions following intentional attacks on public buildings and the nation's water supply. Since 2004, EPA's National Homeland Security Research Center (NHSRC) has been developing the toxicity value database (TVD) to provide quick access to toxicity, critical effect, and benchmark data, as well as chemical properties, and fate and transport data, to support rapid and efficient response during emergency situations.

The TVD can be viewed as a specialist database that offers a "one-stop shop" for 96 agents (see Table 1 for a complete listing) by providing a comprehensive listing of publicly available toxicity benchmark data from secondary sources (national and international), a description of the benchmark derivation, an inventory of agent property

\footnotetext{
is Disclaimer: The opinions expressed within the manuscript do not necessarily represent the views of EPA. Mention of trade names or commercial products does not constitute endorsement or recommendation for use.

* Corresponding author. U.S. EPA, 901 N. 5th Street, Kansas City, KS 66101, ENSV/IO, USA. Fax: +1 9135518752 .

E-mail address: moudgal.chandrika@epa.gov (C.J. Moudgal).
}

information, and a compilation of dose-response information retrieved from the primary scientific literature.

The TVD is one tool among many that NHSRC is currently developing to enable scientists, engineers, and emergency responders to make rapid decisions regarding containment, treatment, decontamination, and disposal of contaminated media. A complete listing of publicly available tools and documentation can be obtained at http:// www.epa.gov/nhsrc/index.htm.

As stated by Anderson et al. (2000), a specialist database is generally more useful and effective than larger commercially available counterparts. Such specialist databases are not necessarily limited to toxicological data, but can be developed for a number of data elements. For example, Anderson et al. (2000) show that a specialist bibliographic toxicity database (TRACE) is more effective compared to larger and more generic bibliographic databases. The distributed structure-searchable toxicity (DSSTox) public database which can be accessed via the following link: http://www.epa.gov/ncct/dsstox/ can be viewed as another specialized database. The database's purpose is to provide the use of a common standard file format that includes chemical structure and property information, a centralized website that enables free public access to structure-toxicity data files and finally engages the public, academia, and industry toward continued contributions and expansion of the database. The database provides opportunities for a closer relationship between a chemical structure 
Table 1

List of agents included in the NHSRC TVD

\begin{tabular}{|c|c|}
\hline CAS \# & Agent name \\
\hline \multicolumn{2}{|c|}{ Chemical warfare agents } \\
\hline $7784-42-1$ & Arsine (SA) \\
\hline $151-50-8$ & Cyanide salts (potassium cyanide) \\
\hline $143-33-9$ & Cyanide salts (sodium cyanide) \\
\hline $506-77-4$ & Cyanogen chloride (CK) \\
\hline 329-99-7 & Cyclohexyl sarin (GF) \\
\hline $505-60-2$ & Distilled mustard/mustard gas (HD) \\
\hline $598-14-1$ & Ethyldichloroarsine (ED) \\
\hline $1189-87-3$ & GE \\
\hline $541-25-3$ & Lewisite (L, L-1) \\
\hline $40334-69-8$ & Lewisite (L-2) \\
\hline 40334-70-1 & Lewisite (L-3) \\
\hline $51-75-2$ & Nitrogen mustard (HN-2) \\
\hline $382-21-8$ & Perfluoroisobutylene (PFIB) \\
\hline $75-44-5$ & Phosgene (choking) (CG) \\
\hline $1794-86-1$ & Phosgene oxime (CX) \\
\hline $7723-14-0$ & Red phosphorus (RP) \\
\hline $107-44-8$ & Sarin (GB) \\
\hline $96-64-0$ & Soman (GD) \\
\hline $77-81-6$ & Tabun (GA) \\
\hline $532-27-4$ & Tear gas (CN) (2-chloroaceto...) \\
\hline $2698-41-1$ & Tear gas (CS) (o-chlorobenz...) \\
\hline $9002-84-0$ & Teflon (PTFE) \\
\hline $7550-45-0$ & Titanium tetrachloride (FM) \\
\hline $21738-25-0$ & VE \\
\hline $78-53-5$ & VG \\
\hline $159939-87-4$ & V-Gas \\
\hline $21770-86-5$ & VM \\
\hline $50782-69-9$ & VX \\
\hline \multicolumn{2}{|c|}{ Toxic industrial chemicals } \\
\hline $116-06-3$ & Aldicarb \\
\hline $7664-41-7$ & Ammonia (anhydrous) \\
\hline $7440-38-2$ & Arsenic (all forms) \\
\hline $22569-72-8$ & Arsenic (trivalent) \\
\hline $10294-34-5$ & Boron trichloride \\
\hline $7637-07-2$ & Boron trifluoride \\
\hline $28772-56-7$ & Bromadiolone \\
\hline $7440-43-9$ & Cadmium \\
\hline $1563-66-2$ & Carbofuran \\
\hline $75-15-0$ & Carbon disulfide \\
\hline $7782-50-5$ & Chlorine \\
\hline $76-06-2$ & Chloropicrin (PS) \\
\hline $535-89-7$ & Crimidine \\
\hline $57-12-5$ & Cyanide \\
\hline $561-27-3$ & Diacetylmorphine \\
\hline $19287-45-7$ & Diborane \\
\hline $62-73-7$ & Dichlorovos \\
\hline $141-66-2$ & Dicrotophos \\
\hline $75-21-8$ & Ethylene oxide \\
\hline $22224-92-6$ & Fenamiphos \\
\hline $7782-41-4$ & Fluorine \\
\hline $50-00-0$ & Formaldehyde \\
\hline $110-00-9$ & Furan \\
\hline 10035-10-6 & Hydrogen bromide \\
\hline 7647-01-0 & Hydrogen chloride \\
\hline $74-90-8$ & Hydrogen cyanide (AC) \\
\hline $7664-39-3$ & Hydrogen fluoride \\
\hline 7783-06-4 & Hydrogen sulfide \\
\hline 7487-94-7 & Mercuric chloride \\
\hline $453-18-9$ & Methyl fluoroacetate \\
\hline $151-38-2$ & Methyloxyethylmercuricacetate \\
\hline 7786-34-7 & Mevinphos \\
\hline $54-11-5$ & Nicotine \\
\hline $7697-37-2$ & Nitric acid, fuming \\
\hline $23135-22-0$ & Oxamyl \\
\hline $10102-43-9$ & Oxides of nitrogen (nitric oxide) \\
\hline $10102-44-0$ & Oxides of nitrogen (nitrogen dioxide) \\
\hline $10544-72-6$ & Oxides of nitrogen (nitrogen tetroxide) \\
\hline $10544-73-7$ & Oxides of nitrogen (nitrogen trioxide) \\
\hline $10024-97-2$ & Oxides of nitrogen (nitrous oxide) \\
\hline $4685-14-7$ & Paraquat \\
\hline $77-10-1$ & Phencyclidine \\
\hline $298-02-2$ & Phorate \\
\hline $7803-51-2$ & Phosphine \\
\hline
\end{tabular}

Table 1 (continued)

\begin{tabular}{ll}
\hline CAS \# & Agent name \\
\hline Toxic industrial chemicals & Phosphorus trichloride \\
$7719-12-2$ & Sodium fluoracetate \\
$62-74-8$ & Strychnine \\
$57-24-9$ & Sulfur dioxide \\
$7446-09-5$ & Sulfuric acid \\
$7664-93-9$ & Tetraethylpyrophosphate (TEPP) \\
$107-49-3$ & Tetramethylenedisulfotetramine \\
$80-12-6$ & Tungsten hexafluoride \\
$7783-82-6$ & \\
& \\
Biotoxins & Microcystin (LR) \\
$111755-37-4$ & Saxitoxin \\
$35554-08-6$ & Alpha amanitin \\
$23109-05-9$ & Brevetoxin \\
$98225-48-0$ & Mycotoxin (trichothecene [T2]) \\
$21259-20-1$ & Aflatoxin B1 \\
$1162-65-8$ & Aflatoxin B2 \\
$7220-81-7$ & Aflatoxin G1 \\
$1165-39-5$ & Aflatoxin G2 \\
$7241-98-7$ & Aflatoxins \\
$1402-68-2$ & Picrotoxin \\
$124-87-8$ & Ricin \\
$9009-86-3$ & \\
& \\
Radiological & Cesium-137 \\
$10045-97-3$ & Strontium-90 \\
$10198-40-0$ & \\
$14694-69-0$ & \\
$10098-97-2$ & \\
\hline
\end{tabular}

and its existing toxicity data and promotes and facilitates structurebased exploration of toxicity data within a chemical structure framework (Richard and Williams, 2002).

Although several toxicity databases are available and provide a wide range of toxicity information, this paper compares the TVD with three systems commonly used by risk assessors and emergency responders. The three databases are the Wireless Information System for Emergency Responders (WISER) (NLM, 2007c, http://wiser.nlm.nih.gov/), Registry of Toxic Effects of Chemical Substances (RTECS) (NIOSH, 2007a, http:// www.cdc.gov/niosh/rtecs/default.html), and TOXicology Date NETwork (TOXNET) which provides links to 14 databases made available by the National Library of Medicine (NLM) (NLM, 2007a, http://toxnet.nlm.nih. gov/). Comparison with a multitude of other databases, both commercial and non-commercial, is beyond the scope of this paper.

Developed by NLM, WISER is a freely available database that provides basic information and guidance for a hazardous material response, including substance identification support, physical characteristics, human health information, containment, cleanup and disposal methods, and suppression guidance (NLM, 2007c, http:// wiser.nlm.nih.gov/). WISER is available in a web-based version or for download to a personal computer or wireless device. The database draws from data maintained in NLM's Hazardous Substance Data Bank (HSDB) and outlines potential health effects for approximately 400 hazardous substances. Unlike the TVD, however, dose-response information for various exposure durations, associated health effects and benchmarks, and reference values from various national and international sources are not available in a synthesized format. In addition, 49 of the 96 agents in the TVD have no entries in WISER.

RTECS is a compendium of data extracted from the open scientific literature and provides toxicity information for more than 160,000 chemicals. RTECS primary users include the chemical industry, and the occupational safety and health community, and can be purchased through the company that currently maintains the database (Elsevier MDL; http://en.wikipedia.org/wiki/Elsevier_MDL). It should be noted that though the database is designated as a primary source of information for Material Safety Data Sheet (MSDS) development, the studies cited in RTECS have not been evaluated; therefore, the user has 
Table 2

Secondary benchmark sources and types in the NHSRC TVD (national)

\begin{tabular}{|c|c|c|}
\hline Source & Benchmark type & Web site \\
\hline $\begin{array}{l}\text { EPA, National Center for Environmental Assessment (NCEA), } \\
\text { Integrated Risk Information System (IRIS) }\end{array}$ & $\begin{array}{l}\text { - Reference Dose (RfD) } \\
\text { - Reference Concentration (RfC) } \\
\text { - Cancer slope factor (CSF) } \\
\text { - Inhalation unit risk (IUR) } \\
\text { - Cancer classification }\end{array}$ & http://www.epa.gov/iris/ \\
\hline EPA, Office of Pesticide Programs (OPP), Re-registration & $\cdot \operatorname{RfD}$ & http://www.epa.gov/pesticides/reregistration/status. \\
\hline Eligibility Decision (RED) & $\begin{array}{l}\text { - Population Adjusted Dose (PAD) } \\
\text { - Drinking Water Level of Comparison (DWLOC) }\end{array}$ & htm \\
\hline EPA, Office of Radiation and Indoor Air (ORIA) & $\begin{array}{l}\text { - Health Effects Assessment Summary Table (HEAST) } \\
\text { CSF values }\end{array}$ & http://www.epa.gov/radiation/heast/download.htm \\
\hline EPA, Office of Water (OW) & $\begin{array}{l}\text { - Maximum Contaminant Level (MCL) } \\
\text {-1-day/10-day Health Advisories (HA); Lifetime } \\
\text { Health Advisory (LTHA); Drinking Water Equivalent } \\
\text { Levels (DWELs) }\end{array}$ & $\begin{array}{l}\text { http://www.epa.gov/safewater/mcl.html } \\
\text { http://www.epa.gov/waterscience/drinking/ } \\
\text { standards/dwstandards.pdf }\end{array}$ \\
\hline Agency for Toxic Substances and Disease Registry (ATSDR) & • Minimal Risk Level (MRL) & http://www.atsdr.cdc.gov/mrls.html \\
\hline National Research Council, National Advisory Committee (NRC/NAC) & - Acute Exposure Guideline (AEGL) & http://www.epa.gov/oppt/aegl/chemlist.htm \\
\hline American Industrial Hygiene Association (AIHA) & • Emergency Response Planning Guidelines (ERPG) & Print copy only available for ERPGs \\
\hline U.S. Department of Energy (DOE) & - Temporary Exposure Evaluation Limit (TEEL) & http://www.eh.doe.gov/chem_safety/teel.html \\
\hline $\begin{array}{l}\text { Centers for Disease Control and Prevention (CDC)/U.S. Army Center } \\
\text { for Health Promotion and Preventive Medicine (USACHPPM) }\end{array}$ & $\begin{array}{l}\text { - Airborne exposure limits (AEL): } \\
\text { - Worker Population Limit (WPL) } \\
\text { - General Population Limit (GPL) } \\
\text { - Immediately Dangerous to Life and Health (IDLH) } \\
\text { - Short-term Exposure Limit (STEL) } \\
\text { - Military Exposure Guideline (MEG) }\end{array}$ & $\begin{array}{l}\text { http://www.gpoaccess.gov/fr/index.html } \\
\text { http://chppm-www.apgea.army.mil/dts/dtchemfs.htm } \\
\text { http://www.chppm.com/, link to Technical Guides, link } \\
\text { to TG-230 with January } 04 \text { Addendum }\end{array}$ \\
\hline National Institute for Occupational Safety and Health (NIOSH) & $\begin{array}{l}\text { - IDLH } \\
\text { - Recommended Exposure Limit (REL): } \\
\text { - Time Weighted Average (TWA) } \\
\text { - STEL } \\
\text { - Ceiling (C) }\end{array}$ & $\begin{array}{l}\text { http://www.cdc.gov/niosh/idlh/intridl4.html } \\
\text { http://www.cdc.gov/niosh/npg/npgdname.html }\end{array}$ \\
\hline Occupational Safety and Health Administration (OSHA) & - Permissible Exposure Limit (PEL) & http://www.osha.gov/SLTC/pel/ \\
\hline American Conference of Government Industrial Hygienists (ACGIH) & $\begin{array}{l}\text { - Threshold Limit Value (TLV): } \\
\text { - TWA } \\
\text { - STEL } \\
\text { - C }\end{array}$ & Print copy only available via ACGIH membership \\
\hline Hazardous Substances Data Bank (HSDB) & LC50, LD50, etc. & http://toxnet.nlm.nih.gov/cgi-bin/sis/htmlgen?HSDB \\
\hline
\end{tabular}

the responsibility for accessing and assessing cited data sources in the database. Toxicity data are organized into six fields in the database and include: 1 ) primary irritation; 2 ) mutagenic effects; 3 ) reproductive effects; 4) tumorigenic effects; 5) acute toxicity; and 6) multiple dose toxicity (NIOSH, 2007b, http://www.cdc.gov/niosh/rtecs/RTECSfeatures.html). With the exception of multiple dose toxicity, the other five toxicity data fields do not lend direct support for rapid risk assessment purposes, although the information is useful in evaluating the overall weight-of-evidence (WOE) of an agent's toxicity. The multiple dose toxicity results include studies of various durations with most common study designs including 13 weeks, 26 weeks, 52 weeks, and 2-year studies (NIOSH, 2007c, http://www.cdc.gov/niosh/pdfs/ 97-119-a.pdf). Since RTECS is not available for open access, unlike the other databases presented here, it is difficult to provide a comparison of the specific elements in the RTECS to specific elements in the TVD.

NLM's TOXNET database is a cluster of 14 databases covering toxicology, hazardous chemicals, environmental health, and related areas. TOXNET provides free access to and easy searching of these 14 databases which include Chem ID Plus ${ }^{\circledR}$, HSDB, TOXLINE ${ }^{\circledR}$, CCRIS (Chemical Carcinogensis Research Information System), DART®/ETIC

Table 3

Secondary agent property sources in the NHSRC TVD

\begin{tabular}{|c|c|c|}
\hline Source & Available information & Web site \\
\hline HSDB & $\begin{array}{l}\text { - Chemical and physical properties } \\
\text { - Environmental fate } \\
\text { - Methods of inactivation } \\
\text { - Synonyms }\end{array}$ & http://toxnet.nlm.nih.gov/cgi-bin/sis/htmlgen?HSDB \\
\hline Environmental Fate Database (EFDB) Chemfate & $\begin{array}{l}\text { - Physical properties } \\
\text { - Environmental fate } \\
\text { - Synonyms }\end{array}$ & http://www.syrres.com/esc/efdb_info.htm \\
\hline Estimation Program Interface for Windows (EPIWIN) & $\begin{array}{l}\text { - SMILES structure } \\
\text { - Physical properties }\end{array}$ & http://www.epa.gov/oppt/exposure/docs/episuitedl.htm \\
\hline National Institutes of Health (NIH) SMILES Translator & - SMILES structure & http://cactus.nci.nih.gov/services/translate/ \\
\hline $\begin{array}{l}\text { National Institute of Standards and Technology (NIST) } \\
\text { Chemistry WebBook }\end{array}$ & - Physical/thermophysical properties & http://webbook.nist.gov/chemistry/ \\
\hline $\begin{array}{l}\text { Chemical Rubber Company (CRC) Handbook of } \\
\text { Chemistry and Physics }\end{array}$ & $\begin{array}{l}\text { - Radioactive decay data } \\
\text { - Physical properties }\end{array}$ & Only hard copy available \\
\hline U.S. Army Field Manual 3-9 & - Chemical and physical properties of warfare agents & http://www.globalsecurity.org/military/library/policy/army/fm/ \\
\hline Munro et al., 1999 & - Chemical and physical properties of warfare agents & $\begin{array}{l}\text { http://ehp.niehs.nih.gov/members/1999/107p933-974munro/ } \\
\text { munro-full.html }\end{array}$ \\
\hline ChemFinder.com & - Physical properties & http://chemfinder.cambridgesoft.com/ \\
\hline
\end{tabular}


(Development and Reproductive Toxicology/Environmental Teratology Information Center), GENETOX (Genetic Toxicology), IRIS (Integrated Risk Information System), ITER (International Toxicity Estimates of Risk), LactMed (Drugs and Lactation), TRI (Toxics Release Inventory), Haz-Map ${ }^{\circledR}$, Household Products Database, and TOXMAP® (NLM, 2007b, http://www.nlm.nih.gov/pubs/factsheets/toxnetfs. html). Though an excellent source for toxicity and other hazard data, one has to compile information from the different databases to obtain dose-response data and critical-effect data. In contrast, the TVD offers the convenience of instant access to quantitative data and associated critical effects from a subset of the TOXNET databases (e.g. HSDB, IRIS, and TOXLINE) for 96 agents. The advantage TOXNET has over the TVD is the availability of a larger subset of chemicals versus the chemicals presented in the TVD. However, depending on the needs of the response community, the number of chemical entries in the TVD can be expanded.

A short summary of the TVD design is presented below along with tables and screen shots to provide a preview of the TVD's operational features.

\section{Toxicity value database design}

The TVD was designed and developed to facilitate data entry, quality assurance and quality control review, and retrieval of compiled data for 96 agents. The key data are presented in a Microsoft Access database with a finite set of reporting features that allow end users to quickly and efficiently extract critical data on agents of interest. The system is populated with toxicity data from publicly available secondary sources, including governmental and non-governmental entities (domestic and international), and from studies in the primary literature from various peer-reviewed journals. Several systems were established during the database development process to ensure technical accuracy, scientific correctness, and proper documentation of the compiled data.

\section{Secondary data sources}

Secondary data sources were used to extract toxicity, critical effect, and associated benchmark data, along with agent properties and fate and transport data, where available. Tables 2 and 3 provide a listing of secondary sources used to populate the TVD with toxicity and chemical property data, respectively. The tables also list web links to the sources, where available. Selection criteria for secondary sources included: 1) publicly available source; 2 ) published or released by a reliable governmental or non-governmental entity; 3) documented peer review and scientific review; and 4) filled a critical need. In most cases, selected benchmark value sources are supported by a rigorous peer review process (e.g. EPA IRIS, ATSDR Toxicological Profiles), but some other sources were included regardless of the peer review rigor to fill an information need (e.g., Department of Energy Temporary Emergency Exposure Limits [TEELs]).

Data elements for agent properties represent quantitative and descriptive information that will be instrumental in identifying an agent and/or in identifying an agent's fate and transport characteristics. For toxicity values, data elements are associated with toxicity benchmarks (e.g., reference values or media-specific health-based guidelines), along with fields to capture the basis for the reported benchmark (e.g., principal studies, supporting benchmark values, observed effect levels, uncertainties, and derivation methods). Table 2 lists the specific types of toxicity benchmarks housed in the TVD.

Table 4

International benchmark sources and types in the NHSRC TVD

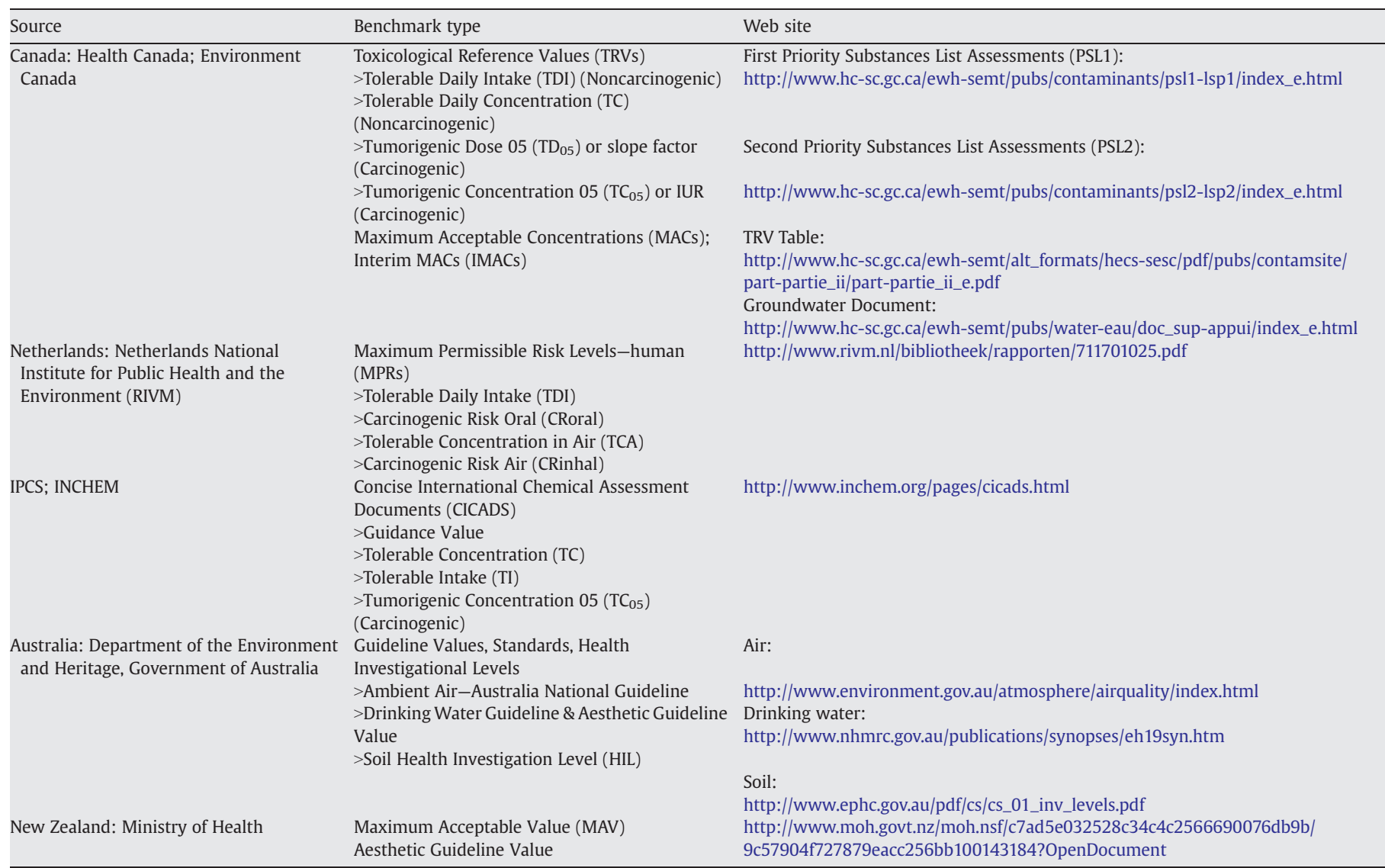




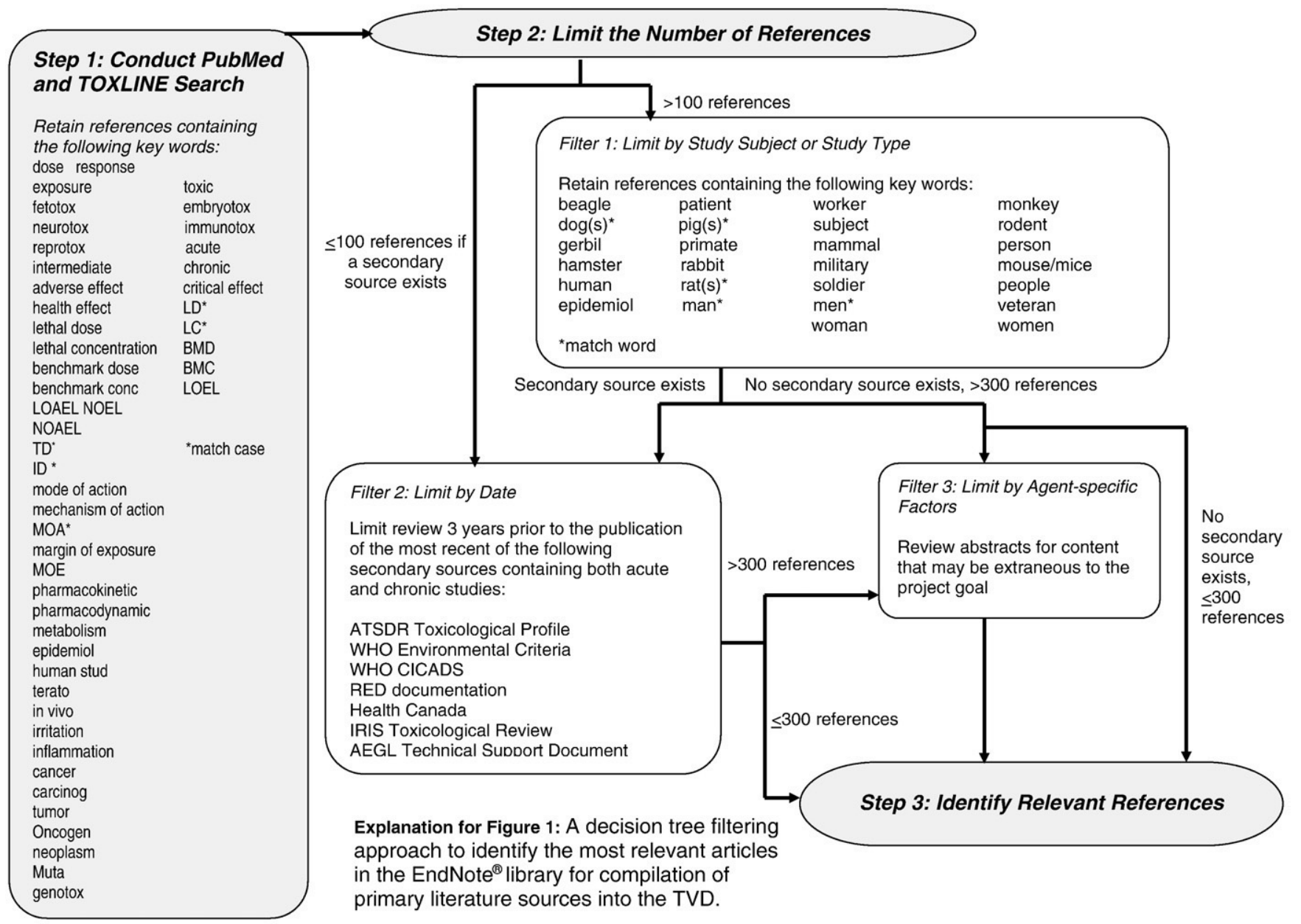

Fig. 1. Decision tree filtering approach.

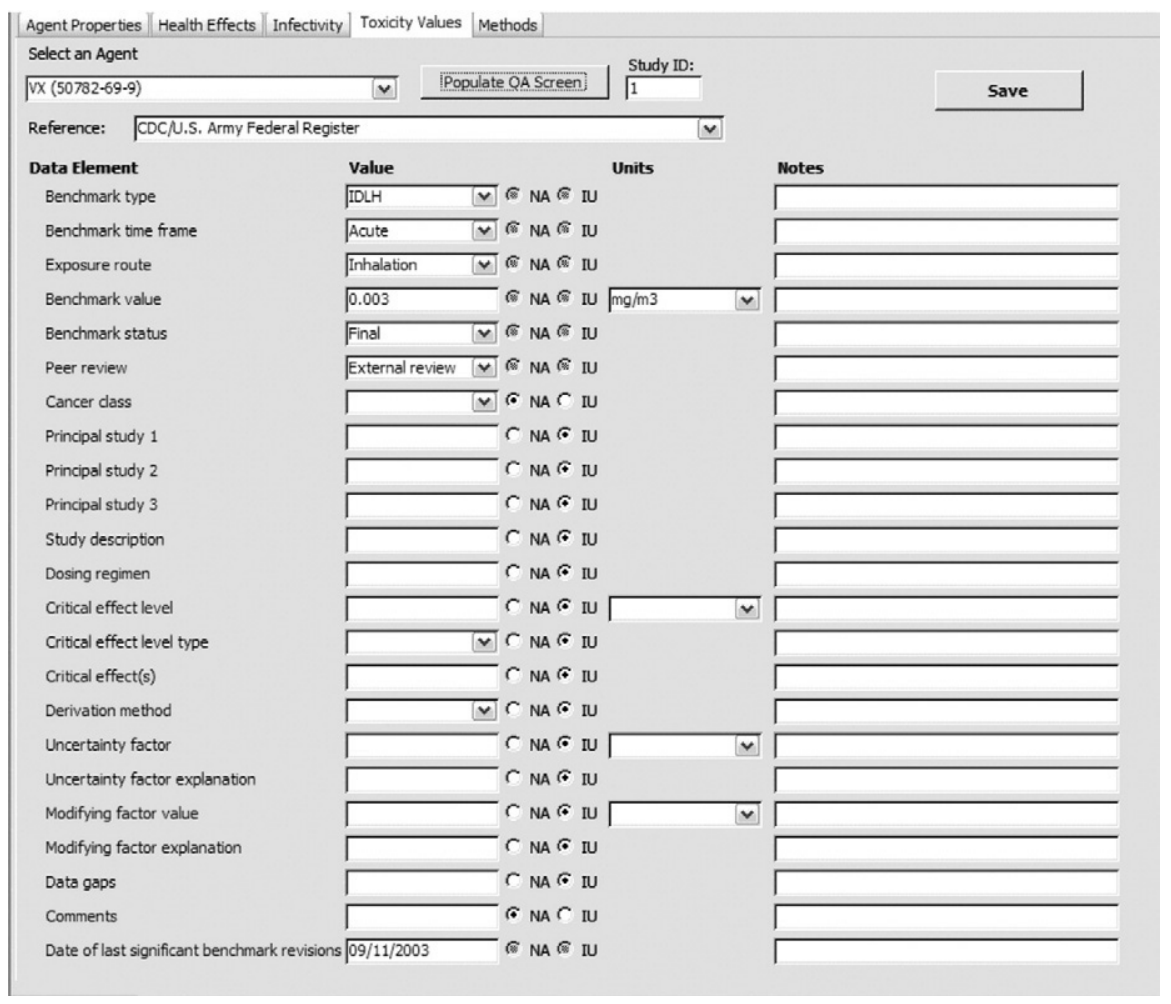

Fig. 2. Sample populated QA/QC data entry form. 
Benchm ark Data Summ ary Report

Agent llame (CAS Number): Paraquat (4685-14-7)

\begin{tabular}{|c|c|c|c|c|c|c|}
\hline \multicolumn{7}{|l|}{ INHRLATION } \\
\hline Benchmark Type & $\frac{\text { Mediz/Toxicity }}{\text { Value }}$ & Benchmark Value & $\underline{\text { Units }}$ & Converted & $\frac{\frac{\text { Specifc Benchmark }}{\text { Timeframe }}}{\text { time }}$ & $\underline{\text { Source }}$ \\
\hline \multicolumn{7}{|l|}{ Acute } \\
\hline TEEL-0 & Media (air) & 0.15 & mgkn3 & $\square$ & 60-minute & U.S. DOE (TEEL) \\
\hline TEEL-1 & Media (air) & 0.15 & mgtn3 & $\square$ & 60-minute & U.S. DOE (TEEL) \\
\hline TEEL-2 & Media (air) & 0.15 & mgtn3 & $\square$ & 60-minute & U.S. DOE (TEEL) \\
\hline TEEL-3 & Media (air) & 150 & mgkn3 & $\square$ & 60 -minute & U.S.DOE(TEEL) \\
\hline \multicolumn{7}{|l|}{ Chronic } \\
\hline TLUTWA & Media (air) & 0.1 & mgkn3 & $\square$ & Chronic & ACGIH \\
\hline TLVTWA & Media (air) & 0.5 & mgth3 & $\square$ & Ohronic & ACGIH \\
\hline PEL-TNAA & Media (air) & 0.5 & mgtn3 & $\square$ & Ohronic & OSHA \\
\hline \multicolumn{7}{|l|}{ ORAL } \\
\hline Benchmark Type & $\frac{\text { MediafToxicity }}{\underline{\text { Value }}}$ & Benchmark Value & Units & Converted & $\frac{\frac{\text { Specifo Benchmark }}{\text { Timeframe }}}{\text { int }}$ & $\underline{\text { Source }}$ \\
\hline \multicolumn{7}{|l|}{ Acute } \\
\hline LO50 & Toxicity & 22 & mgkg & $\square$ & Acute & $\mathrm{HSDB}$ \\
\hline LD50 & Toxisty & 35 & mgkg & $\square$ & Acute & $H S D B$ \\
\hline LD50 & Toxicity & 50 & $\mathrm{mgkg}$ & $\square$ & Acute & HSDB \\
\hline LO50 & Toxicity & 50 & $\mathrm{mgkg}$ & $\square$ & Acute & HSDB \\
\hline LD50 & Toxicty & 50 & mgkg & $\square$ & Acute & $\mathrm{HSDB}$ \\
\hline LD50 & Toxicty & 98 & mgkg & $\square$ & Acute & HSDB \\
\hline LD50 & Toxicity & 155 & $\mathrm{mgkg}$ & $\square$ & Acute & HSDB \\
\hline LD50 & Toxicty & 250 & mgkg & $\square$ & Acute & HSDB \\
\hline LO50 & Toxiơty & 262 & $\mathrm{mgkg}$ & $\square$ & Acute & HSDB \\
\hline \multicolumn{7}{|l|}{ Chronic } \\
\hline RAD & Toxicty & 00045 & $\mathrm{mgkg} / \mathrm{day}$ & $\square$ & Chronic & EPAOP P (RED) \\
\hline TDI & Toxicity & 0001 & mgkg/day & $\square$ & Ohronic & Health Canada-TRV \\
\hline IMAC & Media (water) & 001 & $\mathrm{mgh}$ & $\square$ & Chronic & $\begin{array}{l}\text { Health Canada. } \\
\text { Groundwater }\end{array}$ \\
\hline
\end{tabular}

Fig. 3. Secondary benchmark data summary report.

\section{Benchmark Data Detailed Report}

\section{ACGIH}

\section{Agent Name (CAS Number): Chloropicrin (76-06-2)}

\begin{tabular}{|c|c|}
\hline Data Element & Value \\
\hline Benchmark type & TLV-TWA \\
\hline Benchmark time frame & Chronic \\
\hline Exposure route & Inhalation \\
\hline Benchmark value & $0.1 \mathrm{ppm}$ \\
\hline Benchmark status & Adopted \\
\hline Peer review & Internal agency \\
\hline Cancer class & NA \\
\hline Principal study 1 & $\begin{array}{l}\text { Stokinger, H.E. (1982). Aliphatic nitro compounds, nitrates, nitrites. In: Patty's } \\
\text { Industrial Hygiene and Toxicology, 3rd Rev. ed., Vol. 2C. Toxicology, pp. } 4164- \\
\text { 4166. G.D. Clayton and F.E. Clayton, Eds. John Wiley \& Sons, Inc., New York. }\end{array}$ \\
\hline Principal study 2 & NA \\
\hline Principal study 3 & NA \\
\hline Study description & Human acute study (route not specified) \\
\hline Dosing regimen & 0.3 to $0.37 \mathrm{ppm}$ for 3 to 30 seconds; $15 \mathrm{ppm}$ for 1 minute \\
\hline Critical effect level & $0.3 \mathrm{ppm}$ \\
\hline Critical effect level type & IU \\
\hline Critical effect(s) & Painful irritation of the eye at exposures of 0.3 to $0.37 \mathrm{ppm}$ for 3 to 30 seconds \\
\hline Derivation method & IU \\
\hline Uncertainty factor & IU \\
\hline Uncertainty factor explanation & IU \\
\hline Modifying factor value & IU \\
\hline Modifying factor explanation & IU \\
\hline Data gaps & $\begin{array}{l}\text { Sufficient data were unavailable to recommend Skin or SEN notations or a TLV- } \\
\text { STEL. }\end{array}$ \\
\hline Comments & $\begin{array}{l}\text { TLV minimizes the potential for eye and pulmonary irritation that may progress to } \\
\text { pulmonary edema. Exposure to } 15 \mathrm{ppm} \text { was not tolerated longer than } 1 \text { minute } \\
\text { even by those accustomed to chloropicrin. }\end{array}$ \\
\hline Date of last significant benchmark revisions & 2001 \\
\hline
\end{tabular}

Fig. 4. Secondary benchmark data detailed report. 
International sources

Similar to the secondary sources, international sources include: 1) publicly available source; 2) published or released by a reliable international entity; and 3) documented peer review and scientific review. Similar to secondary data sources, selected benchmark value sources are supported by a peer review process required by the entity that published the benchmark. Table 4 provides an overview of the international sources from which data were extracted for compilation into the TVD.

\section{Primary literature sources}

A tiered approach was used for reviewing and compiling relevant toxicity information from primary literature sources. Fig. 1 provides an overview of the steps followed in the primary literature source selection. The ultimate goal is to identify studies that contain quantitative dose data to be reviewed and evaluated for utility in supporting human health risk assessment and toxicity benchmark development.
As part of Step 1, PubMed (http://www.ncbi.nlm.nih.gov/sites/ entrez?db=pubmed) and TOXLINE (http://www.nlm.nih.gov/pubs/ factsheets/toxlinfs.html) databases were searched for each agent using CAS numbers and synonyms, and all records were inputted into an EndNote ${ }^{\circledR}$ reference library. A decision tree filtering approach was developed and used to identify the most relevant toxicity studies in the EndNote ${ }^{\circledR}$ library for compilation into the TVD. EndNote ${ }^{\circledR}$ records were initially searched using multiple key words. Key words represent terms (full and truncated) aimed at identifying toxicological and epidemiological studies that cover a range of health endpoints (e.g., lethal, fetotox, reprotox, muta, cancer, tumor, irritation) and exposure periods (e.g., acute chronic) of interest, and are likely to present quantitative dose-response data (e.g., NOAEL, BMD). All records containing any of the listed terms were retained. The records were further screened by using the filters in Step 2 .

The goal of Step 2 was to limit the reference list to those most likely to contain experimental animal and epidemiological studies. For agent searches yielding greater than 100 references, another set of key words were applied to limit by study subject or study type (Filter 1 ). In addition, to limit duplication of studies already reviewed as part of

\section{Primary Literature Citation Report}

\section{Agent Name (CAS Number): Diacetylmorphine (561-27-3) Citations}

Antonilli, L. , C. Suriano, et al. (2003). "Repeated exposures to heroin and/or cadmium alter the rate of formation of morphine glucuronides in the rat." J Pharmacol Exp Ther 307(2): 651-60.

Castellano, C. (1980). "Dose-dependent effects of heroin on memory in two inbred strains of mice." Psychopharmacology (Berl) 67(3): $235-9$

Castellano, C., L. Filibeck, et al. (1976). "Effects of heroin, alone or in combination with other drugs, on the locomotor activity in two inbred strains of mice." Psychopharmacology (Berl) 49(1): 29-31.

Chang, A., G. Wood, et al. (1976). "Effects of narcotics on fetal acid base status." Br. J. Obstet. Gynaecol. 83(Jan): 56-61.

Elias-Jones, A. C., D. A. Barrett, et al. (1991). "Diamorphine infusion in the preterm neonate." Arch Dis Child 66(10 Spec No): $1155-7$.

Elliott, H. W. K. D. Parker, et al. (1971). "Actions and metabolism of heroin administered by continuous intravenous infusion to man." Clin. Pharmacol. Ther. 12(Sep-Oct): 806-814.

Fecho, K. and D. T. Lysl (2001). "Acute effects of heroin on the cellularity of the spleen and the apoptosis of splenic leukocytes." Adv Exp Med Biol 493: 153-62.

Fischman, H. K., L. Roizin, et al. (1983). "Clastogenic effects of heroin in pregnant monkeys and their offspring." Mutat Res 118:77-89,1983 Tax - Macaca Mulatta.

Fuller, S. A. and E. A. Stein (1991). "Effects of heroin and naloxone on cerebral blood flow in the conscious rat." Pharmacol Biochem Behav 40(2): 339-44

Hock, C., R. Stormer, et al. (1999). "Heroin-induced deoxygenation of cerebral hemoglobin: monitoring by means of near-infrared spectroscopy." Ann Neurol 45(1): 134-5.

Misiti, A. P. G. Turillazzi, et al. (1991). "Heroin induces changes in mother-infant monkey communication and subsequent disruption of their dyadic interaction." Pharmacol Res 24(1): 93-104.

Mitterhofer, A P., M. Antonelli, et al. (1998). "High-dose intranasal snorted heroin: a new cause of pancreatitis." Pancreas 17(2): 213-5.

Moerschbaecher, J. M. , D. M. Thompson, et al. (1983). "Effects of heroin, methadone, LAAM and cyclazocine on acquisition and performance of response sequences in monkeys." Pharmacol Biochem Behav 19(4): 701-10.

Pena, J., C. Aranda, et al. (1990). "Heroin-induced myopathy in rat skeletal muscle." Acta Neuropathol (Berl) 80(1): 72-6.

Pena, J., E. Luque, et al. (1993). "Experimental heroin-induced myopathy: ultrastructural observations." J Submicrosc Cytol Pathol 25(2): 279-84

Rowlett, J. K and W. L. Woolverton (1995). "Evaluation of the effects of cocaine, heroin and naltrexone, alone and in combination, on milk drinking in rats." Behav Pharmacol 6(8): 821-829.

Sheweita, S. A. (2003). "Narcotic drugs change the expression of cytochrome P450 2E1 and 2C6 and other activities of carcinogen-metabolizing enzymes in the liver of male mice." Toxicology 191 (2-3): 133-42.

Singh, M. E., I. S. McGregor, et al. (2005). "Repeated exposure to Delta(9)-tetrahydrocannabinol alters heroin-induced locomotor sensitisation and Fos-immunoreactivity." Neuropharmacology.

Fig. 5. Primary literature citation report. 
comprehensive literature reviews by authoritative scientific bodies, data limits were applied (Filter 2) if one or more of the following documents were available:

- Agency for Toxic Substances and Disease Registry (ATSDR) Toxicological Profiles

- World Health Organization (WHO) Environmental Criteria Documents

- WHO Concise International Chemical Assessment Documents (CICADS)

- EPA Office of Pesticide Programs Re-registration Eligibility Decision (RED) documentation

- Health Canada Priority Substance List Assessment Report

- EPA IRIS Toxicological Review

- National Research Council/National Advisory Committee Acute Exposure Guideline (AEGL) Technical Support Document

Specifically, only references published 3 years prior to the publication of the most recent comprehensive literature review or later were retained for further review and possible inclusion in the TVD.

If greater than 300 abstracts still remained after Step 2 Filters 1 and 2 , abstracts were reviewed for content that may be extraneous to the project goal. The primary purpose of this filter (Filter 3) was agentspecific and relied on the scientific judgment of the review team.

After limiting the number of citations to a more manageable number in Step 2, abstracts were reviewed during Step 3 to identify articles most likely to contain agent-specific dose-response data. Those articles were retrieved and reviewed in full, with a subset of pertinent studies entered into the TVD. Abstracts that described genotoxicity, biomarkers (without dose-response data), detection/ decontamination methods, exposure countermeasures, or ecotoxicity were excluded from further review.

\section{Quality assurance/quality control}

Prescriptive data-entry protocols were used to ensure consistent data entry from primary and secondary literature sources. In addition, strict $\mathrm{QA} / \mathrm{QC}$ procedures were implemented to ensure that no information was lost, transcribed incorrectly, or compromised when obtained from the original source. Following entry of agent-specific data into the TVD, each and every database record was reviewed to ensure that database records were accurate and complete. A database interface was designed explicitly to enable senior scientists to review and correct database entries as needed. Fig. 2 provides a sample of the $\mathrm{QA} / \mathrm{QC}$ data entry form used to ensure accuracy and completeness.

\section{Data reporting functions}

A finite set of database reporting functions allows the end user to extract data from the TVD. The following six reports are available: 1)

\section{Primary Literature Detailed Report}

\begin{tabular}{|c|c|}
\hline \multicolumn{2}{|l|}{ 7: Dichlorovos (62-73-7) } \\
\hline DataElement & Value \\
\hline Full citation & $\begin{array}{l}\text { Atis, S., U. Comelekoglu, et al. (2002). "Electrophysiological and histopathological } \\
\text { evaluation of respiratory tract, diaphragm, and phrenic nerve after dichlorvos inhalation } \\
\text { in rats." Inhal Toxicol 14(2): 199-215. }\end{array}$ \\
\hline Species studied & Rat \\
\hline Species strain & Wistar albino rat \\
\hline Gender & Male \\
\hline Age & Young adult \\
\hline Number of test subjects & $\begin{array}{l}\text { Electrophysiological investigations: } 30 \text { male rats served as tes subjects and controls; } \\
\text { rats seved as controls prior to inhalation w each dose subsequently administered to } 6 \\
\text { test subjects; histopathologic examination: } 3 \text { rats formed control group }\end{array}$ \\
\hline Administered dosesiexposure levels & $0,1,2,5,10,15$ ug $/ \mathrm{L}$ \\
\hline Duration & $\begin{array}{l}\text { 45-minute exposure followed by electrophy siological examinations at } 30,60-, 120 \text {-, and } \\
180-\text { min post-inhalation wacrifice after } 48 \mathrm{hrs}\end{array}$ \\
\hline Route of exposure & Inhalation \\
\hline Dosing regimen & 45-minute exposure to $98 \%$ pure dichlorvos in a whole-body exposure chamber \\
\hline TKTTD Information & NA \\
\hline General comments & $\begin{array}{l}\text { Noted limitation: did not study AchE activity, although results may originate from } \\
\text { inhibition; MUAP=motor unit action potential (diaphragm parameters); } \\
\text { CMAP=compound muscle action potentials (phrenic nervevariables) }\end{array}$ \\
\hline BMD Modeling & Yes \\
\hline BMD Modeling Rationale & $\begin{array}{l}\text { Good measurements of continuous electrophysiological parameters for } 5 \text { inhalation } \\
\text { exposure levels in rats before and at } 4 \text { time points after exposure. Tables show means } \\
\text { and standard deviations for groups of } 6 \text { animals. Outstanding for BMD modeling. }\end{array}$ \\
\hline Study Strengths & $\begin{array}{l}\text { Excellent study of acute electrophysiological responses in nerves of the diaphragm-one } \\
\text { possible site of action for fatal poisoning (note contrary results in Bird 2003), and at least } \\
\text { an index of effects on other nerves. }\end{array}$ \\
\hline Study Limitations & $\begin{array}{l}\text { Acute experiments are not ideal information for effects of repeated exposures, although } \\
\text { some information relevant to phamacodynamic modeling of repeated exposures is } \\
\text { extractable from data on the time course of reversal over } 3 \text { hours following exposures. }\end{array}$ \\
\hline \multicolumn{2}{|l|}{ Dose ID 1} \\
\hline DoselEffect Level & 0 ugil \\
\hline Subject (dose-specific) & Male Wistar albino rat \\
\hline Primary effect(s) & Control group; baseline data reported \\
\hline Effect level type & NA \\
\hline Secondary effect(s) & NA \\
\hline Dose-specific comments & NA \\
\hline
\end{tabular}

Fig. 6. Primary literature detailed report. 


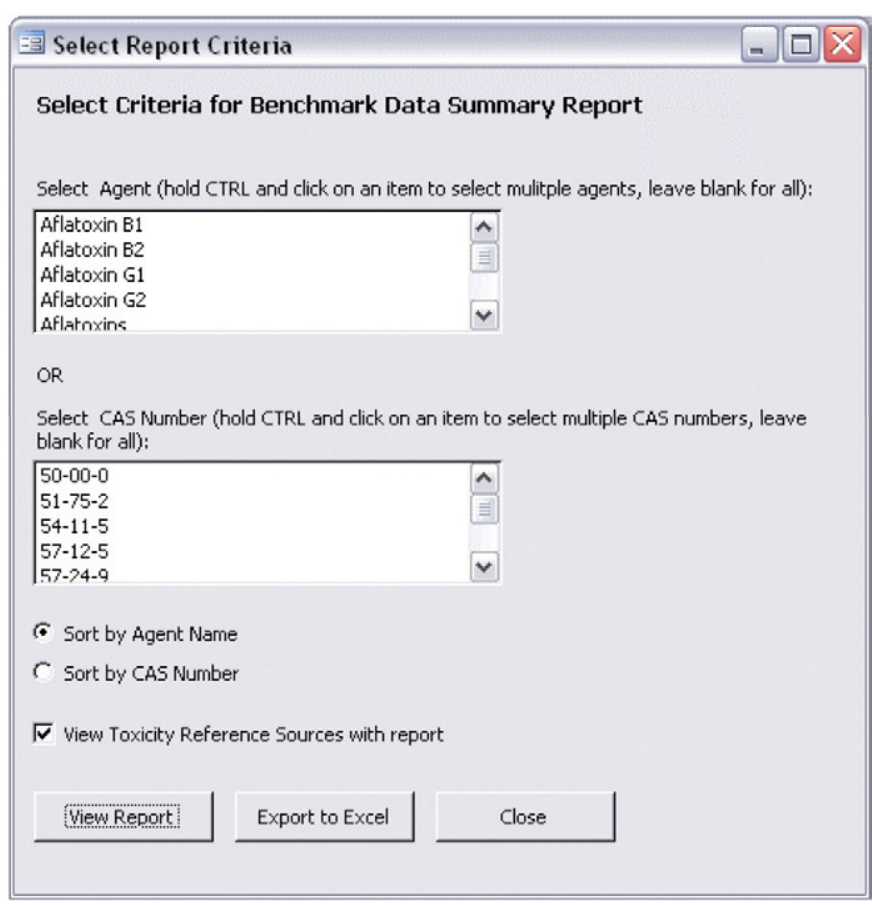

Fig. 7. Select report criteria screen.

agent properties report; 2) synonym report; 3) benchmark data summary report; 4) benchmark data detailed report; 5) primary literature citation report; and 6) primary literature detailed report. The agent properties report and synonym reports list an agent's chemical and physical properties, and possible agent synonyms, respectively. The benchmark data summary report displays a summary of all benchmark types and values housed in the database for a particular agent from national and international secondary sources. The benchmark data detailed report presents available study information supporting each listed benchmark. Figs. 3 and 4 display sample screen shots from benchmark data summary and benchmark data detailed reports, respectively. The primary literature citation report lists references housed in the database and the primary literature detailed report displays detailed reports of primary literature studies (e.g., study design, strengths/weaknesses, and dose-response data). Figs. 5 and 6 display sample screen shots from primary literature citation and primary literature detailed reports, respectively. In addition to providing standard reports in Microsoft Access, the user has the option to export the benchmark data to a Microsoft Excel spreadsheet as shown in Fig. 7.

\section{Discussion}

The TVD currently includes approximately 1900 individual records housing secondary toxicity benchmark information for the 96 agents. In addition, the database includes approximately 1800 individual primary literature records. Secondary source benchmarks include dose levels or exposure guidelines specific to environmental media (air and water) and common exposure routes (inhalation and oral) for worker or general populations. Generally speaking, benchmarks for acute and chronic exposure durations were more prevalent than short-term or subchronic exposure durations. In addition, some benchmark sources were more comprehensive than others and some agents were more widely studied than other agents. The primary literature records represent a cross-section of study types and quick reference to the overall strength and suitability of the study data to support meaningful dose-response analysis. In a limited number of cases, specific benchmarks as presented by study authors are included in the database records (e.g., LD $_{50}$ s, NOAELs/LOAELs).

Given the use of readily accessible secondary sources, a user should recognize the limitations that are inherent in the database. Some limitations include: 1) reliance on information provided in the secondary source data reported in the secondary sources were not verified against the principle studies; and 2) incomplete or limited records due to ambiguity of information in the source documentation.

In conclusion, an attempt was made to make the TVD as comprehensive as possible; however, like a multitude of toxicity databases, the information provided in the database requires scientific judgment and interpretation. Although the information in the TVD is currently limited to 96 agents, it must be emphasized that there is a potential for future growth depending on the needs of the response community. An argument can be made as to "why another database" when there are already several such databases available. However, as pointed out earlier, not all publicly available databases contain all the needed information. The key is to utilize the information available in the TVD in conjunction with other relevant information (e.g. decontamination methods, containment, cleanup, disposal) to make appropriate risk-management decisions that will minimize effects to human health and the environment from intentional releases, accidents, and natural disasters.

Future plans include transferring the stand alone Microsoft Access version of the TVD to an ORACLE web-based system with various search options.

\section{Conflict of interest disclosure statement}

The authors declare that they have no conflicts of interest.

\section{Acknowledgments}

The authors would like to acknowledge Dr. Deborah McKean, Acting Division Director of the Threat and Consequence Management Division, NHSRC, and Ms. Cynthia Sonich-Mullin, Acting Director for Management, NHSRC, for their comprehensive review and recommendations.

This database development was supported by Eastern Research Group Inc., Lexington, MA under GSA contract GS-10F-0036K with the National Homeland Security Research Center, US EPA.

\section{References}

Richard, A.M., Williams, C.R., 2002. Distributed structure-searchable toxicity (DSSTox) public database network: a proposal. Mutat. Res. 499, 27-52.

Anderson, C.A., Copestake, P.T., Robinson, L., 2000. A Specialist toxicity database (TRACE) is more effective than its larger, commercially available counterparts. Toxicology $151,37-43$.

National Institute for Occupational Safety and Health, 2007a. http://www.cdc.gov/ niosh/rtecs/default.html.

National Institute for Occupational Safety and Health, 2007b. http://www.cdc.gov/ niosh/rtecs/RTECSfeatures.html.

National Institute for Occupational Safety and Health, 2007c. http://www.cdc.gov/ niosh/pdfs/97-119-a.pdf2007.

United States National Library of Medicine, 2007a. http://toxnet.nlm.nih.gov/.

United States National Library of Medicine, 2007b. http://www.nlm.nih.gov/pubs/ factsheets/toxnetfs.html.

United States National Library of Medicine, 2007c. http://wiser.nlm.nih.gov/. 